\title{
Biodegradability of dissolved organic carbon in permafrost soils and aquatic systems: a meta-analysis
}

\author{
J. E. Vonk ${ }^{1,2}$, S. E. Tank ${ }^{3}$, P. J. Mann ${ }^{4}$, R. G. M. Spencer ${ }^{5}$, C. C. Treat $^{6}$, R. G. Striegl ${ }^{7}$, B. W. Abbott ${ }^{8}$, and \\ K. P. Wickland ${ }^{7}$ \\ ${ }^{1}$ Department of Earth Sciences, Utrecht University, Utrecht, the Netherlands \\ ${ }^{2}$ Arctic Center, University of Groningen, Groningen, the Netherlands \\ ${ }^{3}$ Department of Biological Sciences, University of Alberta, Edmonton, Canada \\ ${ }^{4}$ Department of Geography, Northumbria University, Newcastle Upon Tyne, UK \\ ${ }^{5}$ Department of Earth, Ocean \& Atmospheric Science, Florida State University, Tallahassee, USA \\ ${ }^{6}$ Earth Systems Research Center, Institute for the Study of Earth, Oceans, and Space, University of New Hampshire, \\ Durham, USA \\ ${ }^{7}$ National Research Program, US Geological Survey, Boulder, Colorado, USA \\ ${ }^{8}$ OSUR-UMR 6553 ECOBIO, Université de Rennes and Centre National de la Recherche Scientifique, Rennes, France
}

Correspondence to: J. E. Vonk (j.e.vonk@uu.nl)

Received: 30 April 2015 - Published in Biogeosciences Discuss.: 8 June 2015

Revised: 13 November 2015 - Accepted: 19 November 2015 - Published: 3 December 2015

\begin{abstract}
As Arctic regions warm and frozen soils thaw, the large organic carbon pool stored in permafrost becomes increasingly vulnerable to decomposition or transport. The transfer of newly mobilized carbon to the atmosphere and its potential influence upon climate change will largely depend on the degradability of carbon delivered to aquatic ecosystems. Dissolved organic carbon (DOC) is a key regulator of aquatic metabolism, yet knowledge of the mechanistic controls on DOC biodegradability is currently poor due to a scarcity of long-term data sets, limited spatial coverage of available data, and methodological diversity. Here, we performed parallel biodegradable DOC (BDOC) experiments at six Arctic sites (16 experiments) using a standardized incubation protocol to examine the effect of methodological differences commonly used in the literature. We also synthesized results from 14 aquatic and soil leachate BDOC studies from across the circum-arctic permafrost region to examine panarctic trends in BDOC.

An increasing extent of permafrost across the landscape resulted in higher DOC losses in both soil and aquatic systems. We hypothesize that the unique composition of (yedoma) permafrost-derived DOC combined with limited prior microbial processing due to low soil temperature and relatively short flow path lengths and transport times, con-
\end{abstract}

tributed to a higher overall terrestrial and freshwater DOC loss. Additionally, we found that the fraction of BDOC decreased moving down the fluvial network in continuous permafrost regions, i.e. from streams to large rivers, suggesting that highly biodegradable DOC is lost in headwater streams. We also observed a seasonal (January-December) decrease in BDOC in large streams and rivers, but saw no apparent change in smaller streams or soil leachates. We attribute this seasonal change to a combination of factors including shifts in carbon source, changing DOC residence time related to increasing thaw-depth, increasing water temperatures later in the summer, as well as decreasing hydrologic connectivity between soils and surface water as the thaw season progresses. Our results suggest that future climate warminginduced shifts of continuous permafrost into discontinuous permafrost regions could affect the degradation potential of thaw-released DOC, the amount of BDOC, as well as its variability throughout the Arctic summer. We lastly recommend a standardized BDOC protocol to facilitate the comparison of future work and improve our knowledge of processing and transport of DOC in a changing Arctic. 


\section{Introduction}

Boreal and Arctic ecosystems contain more than half of global terrestrial organic carbon (Tarnocai et al., 2009; Hugelius et al., 2014), part of which will be vulnerable to microbial processing and release to the atmosphere by the end of the century (Slater et al., 2013; Schaefer et al., 2014; IPCC, 2013). At high latitudes, ecosystem carbon balance depends largely on aquatic processes (Kling et al., 1992; Striegl et al., 2012; Vonk and Gustafsson, 2013) with lakes, wetlands, rivers, and streams covering more than half of the land surface in many regions (McGuire et al., 2009; Loveland et al., 2000; Lammers et al., 2001; Aufdenkampe et al., 2011; Avis et al., 2011). However, little is known about mechanistic controls on persistence or processing of organic carbon currently flowing through Arctic watersheds (Mann et al., 2012; Wickland et al., 2012), and even less is known about the behaviour of permafrost-derived organic carbon that is delivered to arctic freshwater and marine ecosystems (Cory et al., 2013; Vonk and Gustafsson, 2013).

Arctic watersheds transport an average of $34 \mathrm{Tg} \mathrm{C} \mathrm{yr}^{-1}$ of dissolved organic carbon (DOC) and $6 \mathrm{Tg} \mathrm{C} \mathrm{yr}^{-1}$ of particulate organic carbon (POC) to the Arctic Ocean (Holmes et al., 2012; McGuire et al., 2009), not including fluxes from coastal erosion. Though no model projections of future circum-arctic hydrologic carbon flux exist, a few recent studies predict that organic carbon loading to the circum-arctic watershed may increase in the future (Abbott et al., 2015; Laudon et al., 2012; Kicklighter et al., 2013). However, observed patterns of changes in hydrological carbon loading in permafrost regions are inconsistent, with increases in DOC export from areas with extensive peat deposits (Frey and McClelland, 2009), but decreases in discharge-normalized DOC export in other regions, due to increasing flow path lengths and increased mineralization in soils (McClelland et al., 2007; Petrone et al., 2006; Striegl et al., 2005; Tank et al., 2012). Furthermore, conflicting patterns of DOC biodegradability exist with respect to seasonality and permafrost extent (Kawahigashi et al., 2004; Striegl et al., 2005; Holmes et al., 2008; Balcarczyk et al., 2009; Frey and McClelland 2009; Vonk et al., 2013b; Abbott et al., 2014; Larouche et al., 2015). The scarcity of long-term data as well as a lack of conceptualization of the processes controlling DOC transport and processing represent an important source of uncertainty in the permafrost-regional carbon balance.

In both terrestrial and aquatic ecosystems, much of the overall carbon mineralization takes place in the dissolved form, since part of the DOC is composed of lower molecular weight compounds that can be directly transported across microbial cell membranes (Battin et al., 2008), though particulate matter provides surface area for bacterial attachment in aquatic ecosystems (del Giorgio and Pace, 2008). Biodegradable DOC (BDOC), therefore, is a key regulator of ecosystem metabolism in general and the rate of permafrost carbon release to the atmosphere specifically (Holmes et al., 2008;
Mann et al., 2012; Wickland et al., 2012; Abbott et al., 2014). While promising proxies of BDOC have been identified, including optical signatures, molecular characteristics and nutrient concentrations (Balcarczyk et al., 2009; Wickland et al., 2012; Abbott et al., 2014), BDOC is typically assessed through incubation experiments, representing a simple metric of microbial uptake and mineralization. Throughout this study we will use BDOC as a measure of DOC biodegradability. While incubation experiments carried out in the laboratory do not necessarily reflect in situ DOC biodegradability due to many differences including temperature, light, and microbial community, they provide a useful relative measure of the reactivity of different types of DOC. Most studies measure BDOC through: (i) production of dissolved inorganic carbon (DIC), (ii) consumption of DOC, or (iii) consumption of $\mathrm{O}_{2}$ (McDowell et al., 2006). While these methods can give comparable results, differences in experimental factors can directly influence the quantification of BDOC, including duration of incubation, temperature, light exposure, type of filtration, and the addition of bacterial inoculum. While this methodological diversity complicates direct comparison of BDOC measurements from across the Arctic permafrostregion, it also represents an opportunity to identify fundamental controls on DOC processing.

We synthesized results from 14 BDOC studies within the Arctic Ocean watershed representing a total of 551 individual incubations to identify controls and patterns of DOC biodegradability across spatial and temporal scales (Sect. 2.1). Based on findings from these studies we developed a standard incubation method, which we tested on water from soils, streams, and rivers from throughout the permafrost region and across seasons (Sect. 2.2). We examined the role of seasonality, permafrost extent, and incubation design (effect of inoculation) on metrics of BDOC and recommend a protocol for future BDOC incubations. A meta-analysis of the combined results of our standardized circum-arctic incubations and literature synthesis allowed us to identify temporal and landscape-scale patterns in BDOC across Arctic regions. This study represents the first to include both soils (soil leachates) and aquatic systems (streams, lakes, rivers) to explore geographical and seasonal patterns of BDOC in the Arctic.

\section{Methods}

\subsection{Literature synthesis}

We gathered and analysed data from permafrost-region BDOC studies that met the following criteria: (1) located in the Arctic Ocean watershed (including the Yukon River watershed); (2) used DIC production $\left(\mathrm{CO}_{2}\right.$ evasion) or DOC loss over time to assess biodegradability (we excluded studies based on $\mathrm{O}_{2}$ loss due to complicating factors such as res- 
piratory coefficients); and (3) incubation was performed in the dark to avoid autotrophic effects or photodegradation.

A total of 14 studies with experimental data on BDOC were found (Michaelson et al., 1998; Kawahigashi et al., 2004; Wickland et al., 2007, 2012; Holmes et al., 2008; Balcarczyk et al., 2009; Roehm et al., 2009; Kiikkilä et al., 2011; Mann et al., 2012; Olefeldt et al., 2013a, b; Vonk et al., 2013a, b; Abbott et al., 2014). All time steps from the incubations were treated as single data points, thus not just the final DOC loss (e.g. if DOC concentration was measured at days 2, 7, and 14, we included the three points individually). We categorized the data (Table 1 and Fig. 2) by permafrost zone (no permafrost, discontinuous, or continuous), seasonality (day of year), filter pore size $(0.22,0.45$, or $0.7 \mu \mathrm{m})$, BDOC method (DIC production or DOC loss), incubation time/duration (days), incubation temperature, use of inorganic nutrient additions (yes or no), sample agitation during the incubation (yes or no), incubation bottle size (ranging from 40 to $3000 \mathrm{~mL}$ ), inoculum addition at start of experiment (yes or no), and oxygen availability (for soil incubations: oxic or anoxic; all aquatic incubations were performed oxic). When an incubation was performed at "room temperature" we assumed $20^{\circ} \mathrm{C}$. For watersheds crossing permafrost boundaries we chose the spatially dominant permafrost type. We sorted the data into soil leachate and aquatic incubations, with subclasses (for our categorical purposes) for the aquatic data: "lakes", "streams" (<250 km²), "large streams" (250 to $25000 \mathrm{~km}^{2}$ ), "rivers" (25000 to $500000 \mathrm{~km}^{2}$ ) and "large rivers" (> $\left.500000 \mathrm{~km}^{2}\right)$.

\subsection{Circum-arctic standardized incubation experiment}

In June to September of 2013 we performed BDOC experiments with leachates from three soil cores (from near Toolik Field Station, Alaska), water from two streams (Richardson Creek, Alaska; Y3, Siberia), and water from three major Arctic rivers (Yukon, Mackenzie and Kolyma Rivers; Fig. 1). Soil leachates were performed by adding $500 \mathrm{~mL}$ DI water to soil volumes of ca. $2 \mathrm{~L}$, letting this stand for $24 \mathrm{~h}$, and extracting using a pore water sampler measuring total leachate volume extracted. Water samples were collected from the surface in pre-cleaned, pre-rinsed containers and transported (dark and cool) to filtration facilities within $12 \mathrm{~h}$. We developed an incubation methodology adapted for implementation at remote field sites to assure applicability to future work.

We measured DOC loss over time rather than $\mathrm{O}_{2}$ loss or DIC production, as it did not require specialized supplies or instrumentation in the field. All samples were filtered through pre-combusted Whatman GF/F filters (nominal pore size $0.7 \mu \mathrm{m}$ ), which are commonly used throughout the literature and can be pre-cleaned through combustion $\left(450^{\circ} \mathrm{C}>4 \mathrm{~h}\right)$. We set up triplicate incubations with three different treatments to test the effects of bacterial inoculation: (1) no inoculum, (2) $1 \%$ inoculum by volume, (3) $10 \%$ inoculum by volume. Inocula consisted of $1.2 \mu \mathrm{m}$ filtered water (using pre-combusted $\left(450^{\circ} \mathrm{C}>4 \mathrm{~h}\right.$ ) Whatman $\mathrm{GF} / \mathrm{C}$ filters, $1.2 \mu \mathrm{m}$ nominal pore size) that was added to sample waters (filtered at $0.7 \mu \mathrm{m}$ ) to the specified ratio.

We added $30 \mathrm{~mL}$ aliquots of sample into pre-combusted $\left(550^{\circ} \mathrm{C}>4 \mathrm{~h}\right) 40 \mathrm{~mL}$ glass incubation vials and stored them at $20^{\circ} \mathrm{C}$ in the dark, with no nutrient amendment. To ensure oxic conditions we left vial caps loose and shook samples once a day. The incubated samples were re-filtered through $0.7 \mu \mathrm{m}$ filters (using pre-combusted glass filter tower units with $25 \mathrm{~mm}$ GF/F filters or a cleaned syringe filter assembly) to remove flocculation after $0,2,7,14$ and 28 days (using separate vials, in triplicate, for each time step). Re-filtration removes the majority of the microbial biomass, resulting in a measured DOC loss including both DOC mineralization and assimilation. Samples were immediately acidified with $30 \mu \mathrm{L}$ of concentrated $\mathrm{HCl}$ (high quality grade; to $\mathrm{pH} \leq 2$ ). Acidified sample vials were capped and stored refrigerated in the dark until analysis within 3 months. At the time of analysis, acidified samples were sparged with $\mathrm{CO}_{2}$ free air for $8 \mathrm{~min}$ at $75 \mathrm{~mL} \mathrm{~min}^{-1}$ and run as non-purgable organic carbon (NPOC) on either a Shimadzu TOC-V or TOC-L analyzer. DOC was calculated as the mean of between three and seven injections and the coefficient of variance was always $<2 \%$. BDOC is reported in percent loss at time point $x(2,7,14$ or 28 days $)$ according to:

$$
\begin{aligned}
\operatorname{BDOC}(\%)_{T=x}= & \left(\left(\mathrm{DOC}_{T=0}-\mathrm{DOC}_{T=x}\right) / \mathrm{DOC}_{T=0}\right) \\
& \times 100 \%
\end{aligned}
$$

\subsection{Statistical analyses}

We combined the literature meta-analysis of 14 papers $(n=$ $551)$ with data from our circum-arctic incubation experiment ( $n=192$ ). Each of the studies identified used different methods for assessing BDOC, complicating and limiting possible analyses. To examine trends across the total data set $(n=$ 743) we performed categorical principle component analysis (CATPCA) via optimal scaling. This approach allowed us to compare the effect of multiple variables with mixed measurement levels (scalar, nominal, ordinal). We then performed a standard principle component analysis (PCA) using the optimally scaled results to aid in data interpretation. Data normality was assessed using the Shapiro-Wilk test $(p>0.05)$. The data were normal and did not require transformation. Separate CATPCA and PCA analyses were performed on the aquatic and soil leachate data sets, as well as for methodological and environmental parameters (Table 1). Validity of each PCA was tested using the Barlett tests of sphericity $(p<0.001)$ and Kaiser-Meyer-Olkin measures of sampling adequacy. Direct oblimin rotation was applied and rotated scores used throughout, allowing for correlation between scores (Manisera et al., 2010). CATPCA runs assigned measures from scalar data (initial DOC, BDOC (\%), latitude, longitude, Julian day, bottle size, incubation time, and incubation temperature), nominal data (method of $\mathrm{C}$ loss, shak- 
Table 1. List of methodological and environmental parameters we included in our meta-analysis. Variables are classified as scalar (no symbol), nominal $(*)$ and ordinal $(* *)$. For scalar parameters we have listed the data range, for categorical (nominal and ordinal) data we have listed the number of categories along with their definition.

\begin{tabular}{|c|c|c|c|c|c|}
\hline \multirow[t]{3}{*}{ Parameter } & \multirow[t]{3}{*}{ Unit } & \multicolumn{4}{|c|}{ Type of data and range or categories } \\
\hline & & \multirow{2}{*}{$\begin{array}{l}\text { Scalar } \\
\text { Data range } \\
\text { categories }\end{array}$} & \multicolumn{2}{|r|}{ Categorical } & \multirow[b]{2}{*}{ Comments } \\
\hline & & & $\begin{array}{l}\text { Number of } \\
\text { categories }\end{array}$ & $\begin{array}{l}\text { Definition of categories } \\
\text { (PCA value assigned) }\end{array}$ & \\
\hline BDOC & $\%$ & $0-67$ & & & \\
\hline \multicolumn{6}{|l|}{ Methodological } \\
\hline Nutrients* & - & & 2 & $\begin{array}{l}\text { No nutrients (1) - nutri- } \\
\text { ents added (2) }\end{array}$ & \\
\hline Filter pore size ${ }^{* *}$ & $\mu \mathrm{m}$ & & 3 & $\begin{array}{l}0.7(1)-0.45(2)-0.2 \\
(3)\end{array}$ & \\
\hline Inoculation* & - & & 2 & $\begin{array}{l}\text { Not inoculated (1) - in- } \\
\text { oculated (2) }\end{array}$ & $\begin{array}{l}\text { For experimental data, we identified not inoculated - } \\
1 \% \text { inoculated }-10 \% \text { inoculated }\end{array}$ \\
\hline Shaking* & - & & 2 & $\begin{array}{l}\text { No shaking (1) - shak- } \\
\text { ing (2) }\end{array}$ & \\
\hline Oxygen* & - & & 2 & Anoxic (1) - oxic (2) & $\begin{array}{l}\text { All aquatic incubations were assumed to be performed } \\
\text { under oxic conditions }\end{array}$ \\
\hline Bottle size & $\mathrm{mL}$ & $40-3000$ & & & \\
\hline Method of analysis* & - & & 2 & $\begin{array}{l}\text { DIC production (1) - } \\
\text { DOC loss (2) }\end{array}$ & \\
\hline Incubation temperature & ${ }^{\circ} \mathrm{C}$ & $3.5-25$ & & & $\begin{array}{l}\text { In the literature synthesis, we assumed "room } \\
\text { temperature" was } 20^{\circ} \mathrm{C} \text {. }\end{array}$ \\
\hline Incubation time & days & $1-97$ & & & \\
\hline \multicolumn{6}{|l|}{ Environmental } \\
\hline Permafrost** & - & & 3 & $\begin{array}{l}\text { No permafrost (1) dis- } \\
\text { continuous }(2)-\text { contin- } \\
\text { uous (3) }\end{array}$ & Dominant permafrost type in each catchment was used. \\
\hline Location in aquatic network* & - & & 6 & $\begin{array}{l}\text { Soil leachate (1) - lake } \\
\text { (2) - stream (3) - large } \\
\text { stream (4) - river (5) - } \\
\text { large river (6) }\end{array}$ & $\begin{array}{l}\text { Based on watershed size: streams }<250 \mathrm{~km}^{2} \text {; large } \\
\text { streams } 250-25000 \mathrm{~km}^{2} \text {; rivers } 25000-500000 \mathrm{~km}^{2} \text {; } \\
\text { large rivers }>500000 \mathrm{~km}^{2}\end{array}$ \\
\hline Soil or aquatic* & - & & 2 & Aquatic (1) - soil (2) & \\
\hline Latitude & ${ }^{\circ} \mathrm{N}$ & $55.82-70.33$ & & & \\
\hline Longitude & ${ }^{\circ} \mathrm{E}$ & $-162.88-161.45$ & & & ${ }^{\circ} \mathrm{W}$ is given as negative ${ }^{\circ} \mathrm{E}$ degrees \\
\hline Julian day & - & $12-288$ & & & \\
\hline Initial DOC & $\mathrm{mg} \mathrm{L}^{-1}$ & $1.9-155$ & & & \\
\hline
\end{tabular}

ing, nutrient addition, inoculum, oxygen availability, location in fluvial network) and ordinal data (filter pore size, and permafrost extent). We considered final rotated PCA correlations of $>0.7$ as strong, between 0.5 and 0.7 as moderate, and $<0.5$ as weak or absent (Quinn and Keough, 2002). Although this approach has drawbacks, in our opinion it proved the most representative methodology given the diverse data set which included repeated measures (i.e. multiple time points) of BDOC (Bradlow et al., 2002). Additionally, we combined data from all studies carried out with incubation temperatures between $15-25^{\circ} \mathrm{C}$ and with incubation durations between 28-34 days, which represented the most common temperature and duration in the meta-analysis, to test for environmental trends (Figs. 3, 4, 5). Here we tested for differences among means using analysis of variance (ANOVA). All ANOVA, CATPCA, and PCA analyses were conducted in SPSS 22.

\section{Results}

\subsection{Literature synthesis}

The 14 literature studies comprised a total of 551 data points of which 418 were aquatic. Most studies were located in North America (242 data points in Alaska, USA and 227 in Canada; Fig. 2a), and from regions either without permafrost (234), or with continuous permafrost (230; Fig. 2c). The most common incubation temperatures were 17.5 or $20^{\circ} \mathrm{C}$ (41 and $36 \%$ of the data, respectively; Fig. $2 \mathrm{~d}$ ). The majority of studies $(60 \%$ of data) used $0.7 \mu \mathrm{m}$ glass fiber filters to determine DOC (Fig. 2f). Half of the BDOC assays were incubated for between 14 and 40 days (Fig. 2e). Furthermore, most incubations in our synthesis were started after addition of an inoculum as described in the individual studies $(80 \%$ of aquatic incubations, $97 \%$ of soil leachate incubations). 


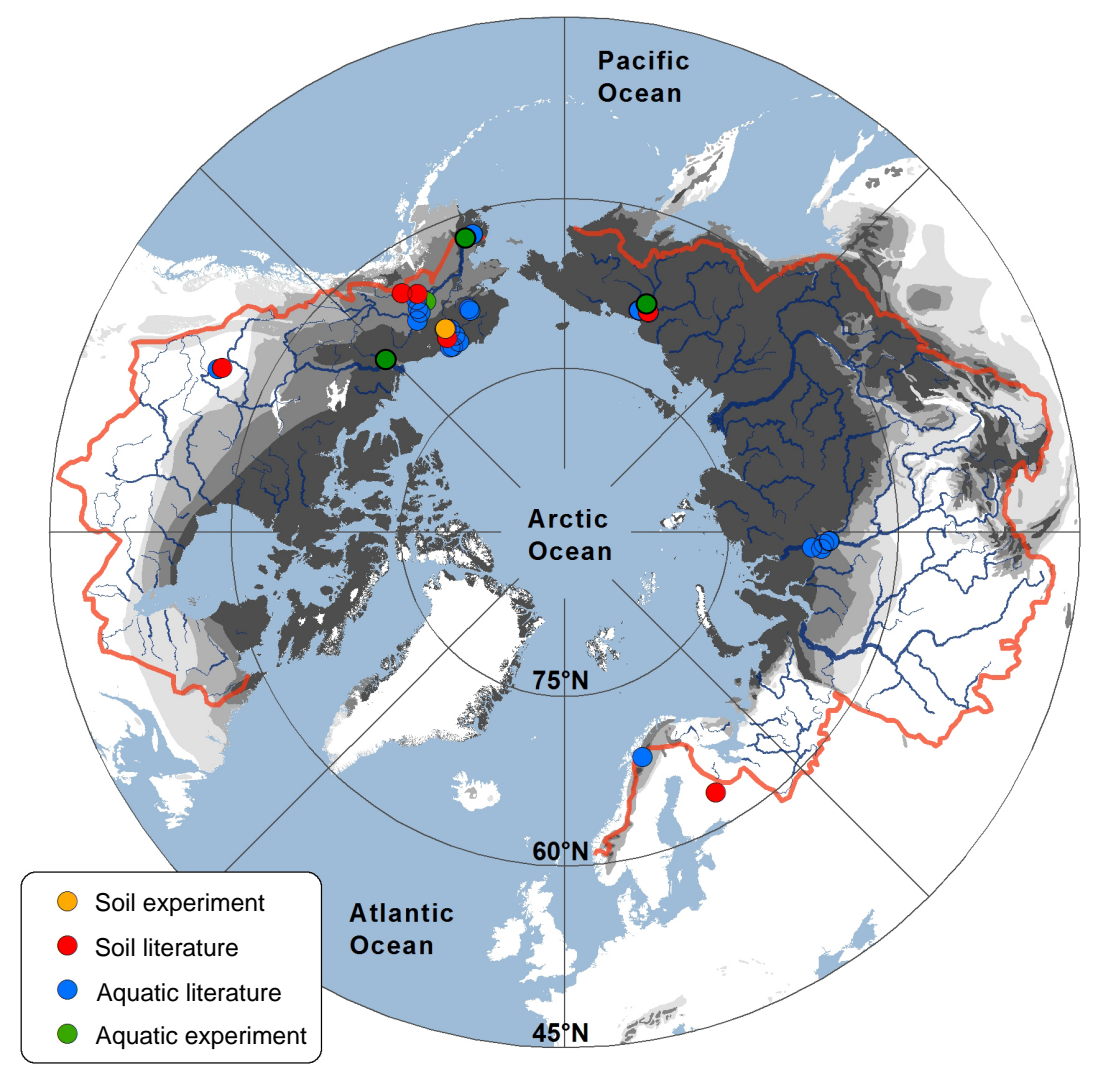

Figure 1. Map of the hydrological network (blue) in the Arctic Ocean watershed (boundary in red) with points showing literature data (blue for aquatic, red for soil) and experimental data (green for aquatic, orange for soil).

\subsection{Methodological factors affecting BDOC}

To examine the effects of inoculum addition and inoculum concentration on BDOC, we compared mean BDOC across our circum-arctic standardized incubation experiment (no inoculum, 1 and $10 \%$ inoculum; $n=40$ per treatment). Amount of inoculum (1\% or $10 \%$ ) had no effect on the proportion of BDOC (ANOVA, $p>0.9$ ). As the degree of inoculation had no clear systematic effect on BDOC loss (see also methodological PCA results; Sect. 3.2.1) we grouped all inoculated data (independent of concentration), and all non-inoculated data during our ANOVA and environmental PCA analyses. In the sections below we examine the patterns present in the combined analysis of aquatic and soil literature results, including our circum-arctic incubation experiments.

\subsubsection{Aquatic BDOC}

Three principle components together explained $81 \%$ of the variance among all aquatic incubation samples $(\mathrm{PC} 1=46$, $\mathrm{PC} 2=23$, PC3 $=12 \%$; Table 2). The first component did not correlate with BDOC but correlated positively with shaking during incubation $(r=0.97)$, the method used to measure DOC loss $(r=0.91)$, incubation temperature $(r=0.84)$, and correlated negatively with bottle size $(r=-0.77)$ and presence of inoculum $(r=-0.51)$. Component 2 also did not explain much variation in BDOC, but correlated with filter pore size $(r=0.90)$, nutrient addition $(r=0.90)$, and the use of inoculum $(r=0.64)$. Component 3 explained the greatest proportion of BDOC variance $(r=-0.83)$. Component 3 also closely correlated with incubation time $(r=-0.85)$ and displayed a negative correlation with bottle size $(r=0.54)$. Effect of oxygen availability was not examined in aquatic incubations, as all previously published experiments were conducted under oxic conditions.

\subsubsection{Soil leachate BDOC}

Three principle components explained $72 \%$ of the variance across all soil incubation samples $(\mathrm{PC} 1=34 \%, \mathrm{PC} 2=21 \%$, $\mathrm{PC} 3=16 \%$; Table 2 ). Component 1 was strongly correlated with BDOC loss $(r=0.75)$, as well as the availability of oxygen in incubations $(r=0.94)$, the method used to measure carbon loss $(r=0.87)$ and whether samples were shaken during incubation $(r=0.73)$. Neither component 2 nor 3 closely correlated with BDOC, but component 2 correlated positively with incubation time $(r=0.88)$, filter pore size $(r=0.74)$ and temperature $(r=0.54)$, and component 3 was 

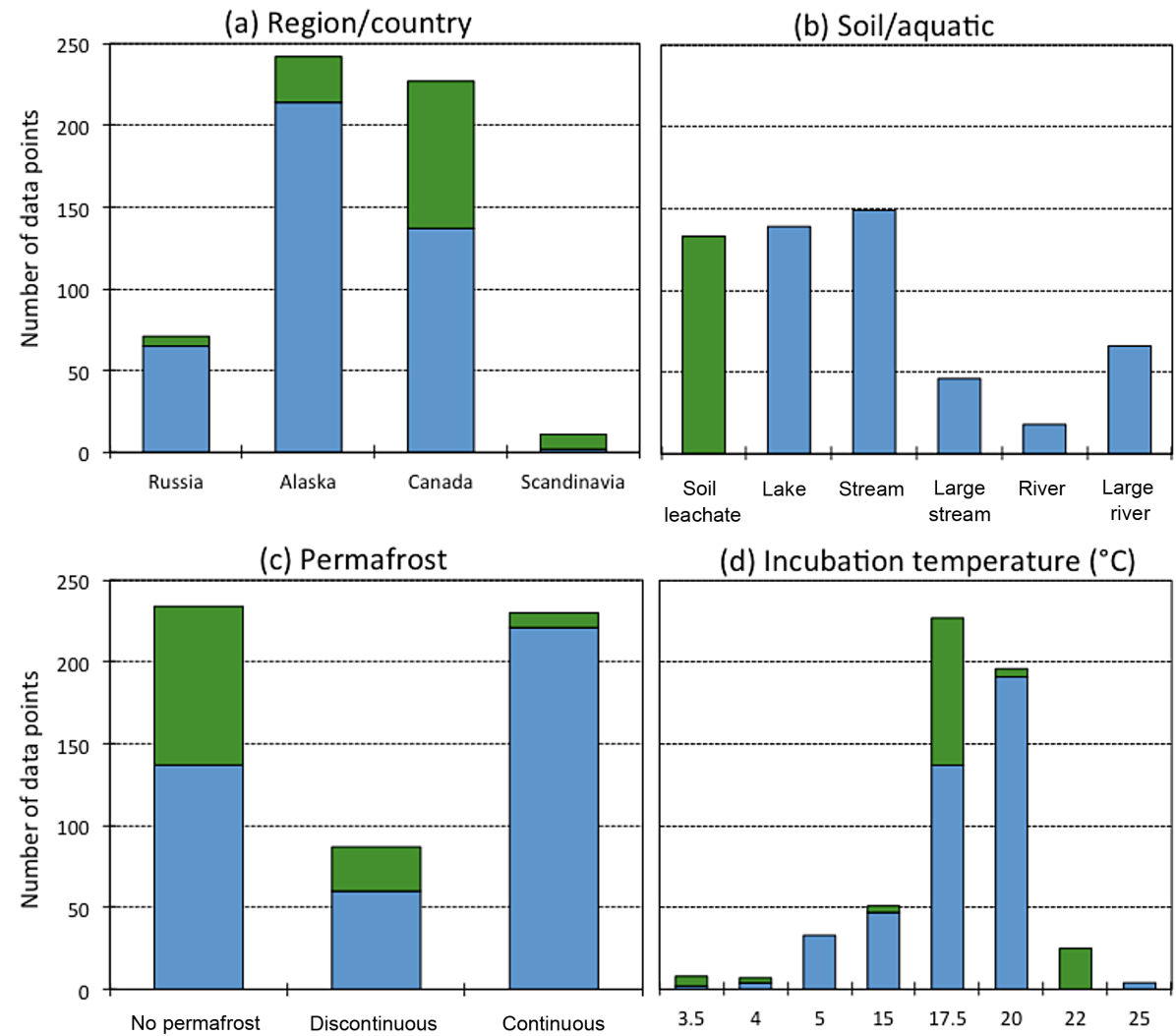

(d) Incubation temperature $\left({ }^{\circ} \mathrm{C}\right)$
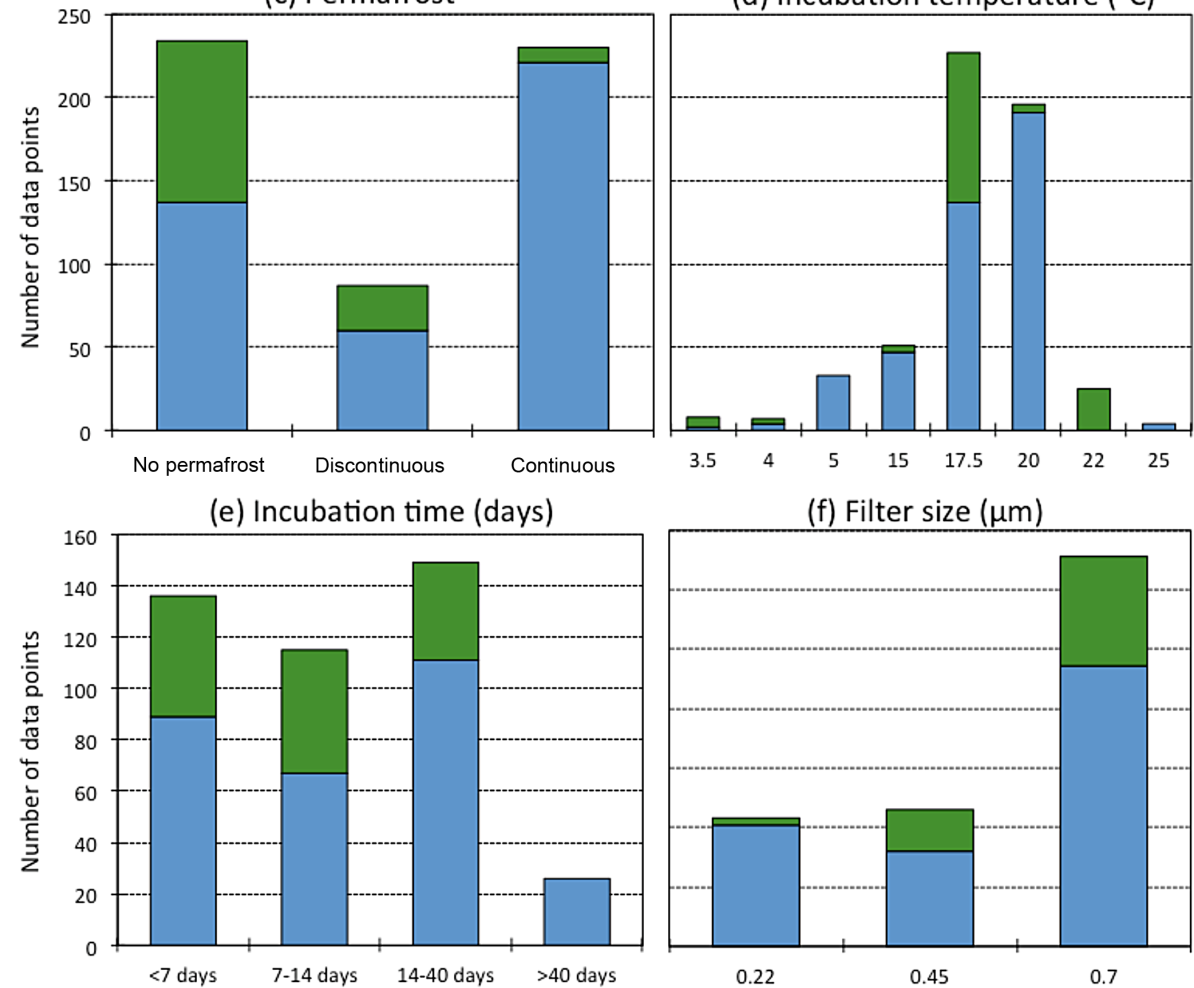

Figure 2. Histograms of environmental and methodological variety reported in the synthesized literature $(n=426$, see Sect. 2.3), with (a) region/country, (b) soil leachate and type of aquatic study (categorized as streams $\left(<250 \mathrm{~km}^{2}\right)$, large streams $\left(>250\right.$ and $\left.<25000 \mathrm{~km}^{2}\right)$, rivers $\left(>25000\right.$ and $<500000 \mathrm{~km}^{2}$ ) and large rivers $\left(>500000 \mathrm{~km}^{2}\right)$ ), (c) permafrost zonation, (d) incubation temperature in ${ }^{\circ} \mathrm{C}$, (e) incubation time (categorized in $<7$ days, 7-14 days, 14-40 days, and >40 days, and (f) filtration pore size $(\mu \mathrm{m})$. Green represents soil leachate data, blue represents aquatic data. The $y$ axis shows number of data points.

positively correlated to bottle size $(r=0.74)$ and inoculum $(r=0.57)$ and negatively related to temperature $(r=-0.66)$ and shaking $(r=-0.57)$.

\subsection{Environmental factors affecting BDOC}

Similar to Sect. 3.2, here we present the statistical results of the fully grouped data set (i.e. inoculated and non-inoculated literature synthesis data, combined with the circum-arctic in- cubation experiment data), concentrating on how environmental variables co-vary with BDOC losses.

\subsubsection{Aquatic BDOC}

Three components explained $82 \%$ of the total variance among environmental parameters from all aquatic incubations $(\mathrm{PC} 1=52 \%, \mathrm{PC} 2=18 \%, \mathrm{PC} 3=13 \%$; Table 3$)$. The first component was moderately correlated with BDOC $(r=0.51)$ and strongly correlated with location within 
Table 2. Correlations between methodological variables and BDOC for each principle component axis $(1,2,3)$ in a structure matrix for aquatic incubations (530 data points) and soil incubations (202 data points). Correlations above 0.7 (in bold) are considered strong, and correlations above 0.5 (italic) as moderate. All aquatic samples were incubated under oxic conditions and so this was excluded from the PCA. Similarly, none of the soil incubations were nutrient-amended so this was excluded from PCA. The parameters are ordered based upon their importance to explaining axis 1. Variables are classified as scalar (no symbol), nominal (*) and ordinal (**).

\begin{tabular}{lrrr}
\hline & \multicolumn{3}{c}{ Aquatic } \\
\cline { 2 - 4 } & 1 & 2 & 3 \\
\hline Shaking* $^{*}$ Method C loss* & $\mathbf{0 . 9 7}$ & 0.07 & -0.46 \\
Temperature & $\mathbf{0 . 9 1}$ & 0.09 & -0.30 \\
Bottle size & $\mathbf{0 . 8 4}$ & 0.11 & -0.18 \\
Filter pore size** & $-\mathbf{0 . 7 7}$ & 0.08 & 0.54 \\
Nutrient addition* & 0.34 & $\mathbf{0 . 9 0}$ & -0.44 \\
Inoculum** & 0.37 & $\mathbf{0 . 9 0}$ & -0.45 \\
Incubation time & -0.51 & 0.64 & 0.32 \\
BDOC & 0.34 & 0.12 & $-\mathbf{0 . 8 5}$ \\
\hline \% variance explained & 0.23 & 0.26 & $-\mathbf{0 . 8 3}$ \\
\hline & 46 & 23 & 12 \\
\hline & & Soil & \\
\cline { 2 - 4 } & 1 & 2 & 3 \\
\hline O $_{2}$ availability* & $\mathbf{0 . 9 4}$ & -0.16 & -0.06 \\
Method C loss* & $\mathbf{0 . 8 7}$ & -0.30 & 0.02 \\
BDOC & $\mathbf{0 . 7 5}$ & 0.37 & -0.02 \\
Shaking* & $\mathbf{0 . 7 3}$ & -0.05 & -0.57 \\
Incubation time & 0.06 & $\mathbf{0 . 8 8}$ & -0.13 \\
Filter pore size** & -0.25 & $\mathbf{0 . 7 4}$ & 0.25 \\
Bottle size & 0.06 & 0.10 & $\mathbf{0 . 7 4}$ \\
Temperature & -0.05 & 0.54 & $-\mathbf{0 . 6 6}$ \\
Inoculum* & -0.44 & 0.08 & 0.57 \\
\hline variance explained $^{*}$ & 34 & 21 & 16 \\
\hline
\end{tabular}

the fluvial network $(r=0.95)$, dominant permafrost type $(r=0.94$; greater BDOC in continuous permafrost regions, see also Fig. 3a), sample latitude ( $r=0.93)$, and initial DOC $(r=-0.70)$. The second component was strongly negatively correlated with BDOC $(r=-0.71)$, and was explained by sample longitude $(r=0.78)$. The third component did not correlate to BDOC but showed a strong correlation with sampling period (Julian day; $r=0.95$ ).

\subsubsection{Soil leachate BDOC}

Two components explained $77 \%$ of the variance in environmental parameters across soil leachate incubations $(\mathrm{PC} 1=55 \%, \mathrm{PC} 2=22 \%$; Table 3$)$. BDOC was most closely correlated to component $1(r=0.81)$, which was associated with latitude $(r=0.97)$ and dominant permafrost type $(r=0.96$; greater BDOC in continuous permafrost re-
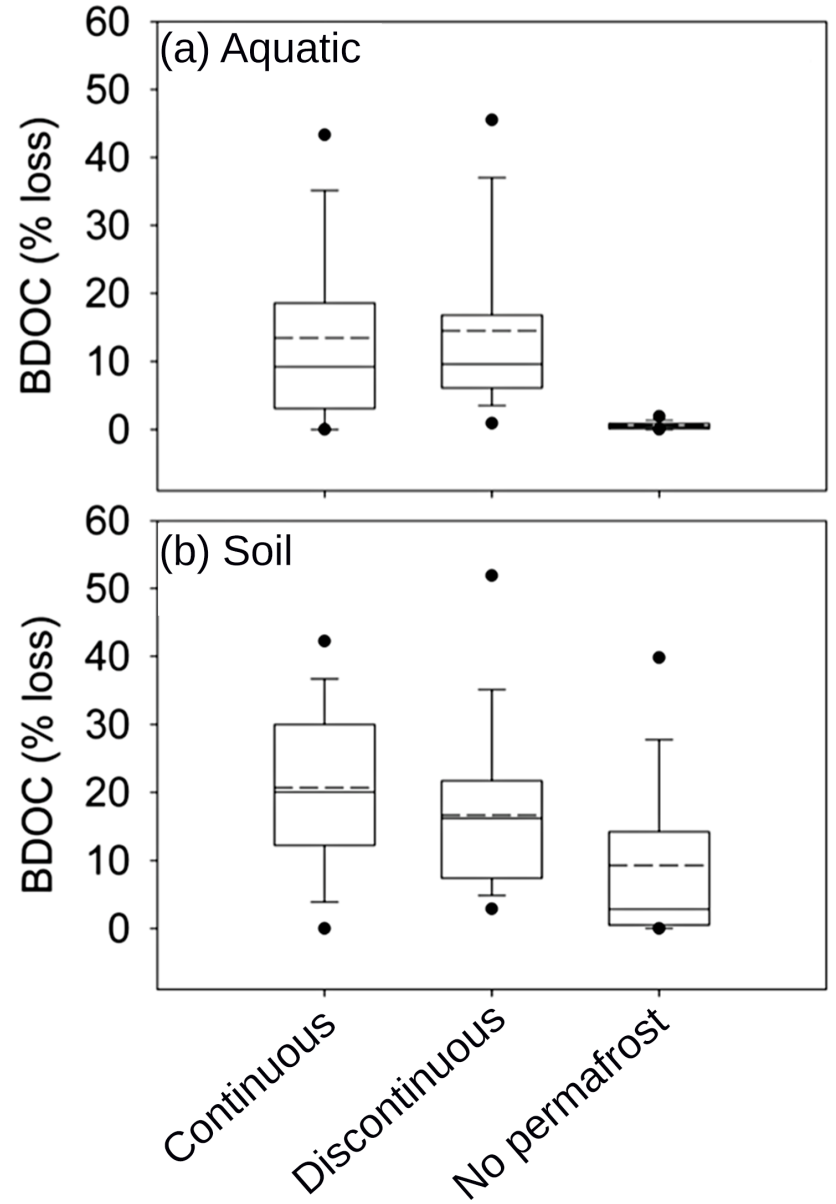

Figure 3. (a) Aquatic and (b) soil leachate BDOC data $\left(15-25^{\circ} \mathrm{C}\right.$, $n=205$ ) after $28-34$ days incubation across dominant permafrost type from literature-synthesis and our circum-arctic experiment. The data are shown as 5th to 95th percentiles (points), 25th, 50th, and 75th percentiles (lines), median value (bold line) and mean value (dashed line). The number of data points used are listed below the box plots.

gions; see also Fig. 3b), and initial DOC ( $r=-0.83)$. The second component did not correlate with BDOC but was positively correlated to longitude $(r=0.79)$ and sampling period (Julian day; $r=0.78$ ).

\section{Discussion}

\subsection{Methodological factors influencing BDOC}

Aquatic BDOC losses only showed a strong correlation with incubation time, with higher total BDOC observed in longer experiments (Table 2). This is not surprising yet does point out that the length of the incubation set-up will ultimately be a primary factor determining the $\mathrm{BDOC}(\%)$, and thus the importance of this consideration for comparison among stud- 
Table 3. Correlations between environmental variables and BDOC for each principle component axis in a structural matrix for aquatic incubations (505 data points) and soil incubations (165 data points). Correlations above 0.7 (in bold) are considered strong, and correlations above 0.5 (italic) as moderate. The parameters are ordered based upon their importance to explaining factor 1. Variables are classified as scalar (no symbol), nominal $(*)$ and ordinal $(* *)$. Location in stream network, i.e. streams, large streams, rivers and large rivers, is indicated as "network".

\begin{tabular}{|c|c|c|c|}
\hline & \multicolumn{3}{|c|}{ Aquatic } \\
\hline & 1 & 2 & 3 \\
\hline Network* & 0.95 & -0.05 & -0.21 \\
\hline Permafrost** & 0.94 & 0.05 & -0.06 \\
\hline Latitude & 0.93 & 0.06 & -0.07 \\
\hline DOC initial & -0.70 & -0.11 & 0.47 \\
\hline Longitude & 0.41 & 0.78 & 0.12 \\
\hline BDOC & 0.51 & -0.71 & -0.05 \\
\hline Julian day & -0.14 & 0.11 & 0.95 \\
\hline \multirow[t]{3}{*}{$\%$ variance explained } & 52 & 18 & 13 \\
\hline & \multicolumn{2}{|c|}{ Soil } & \\
\hline & 1 & 2 & \\
\hline Latitude & 0.97 & -0.08 & \\
\hline Permafrost** & 0.96 & -0.13 & \\
\hline DOC initial & -0.83 & 0.30 & \\
\hline BDOC & 0.81 & 0.15 & \\
\hline Longitude & -0.22 & 0.79 & \\
\hline Julian day & 0.06 & 0.78 & \\
\hline$\%$ variance explained & 55 & 22 & \\
\hline
\end{tabular}

ies. Despite total DOC loss increasing with longer incubation time, the rate of DOC loss decreases over time.

Soil leachate BDOC was not clearly affected by incubation time across experiments (Table 2). We suggest that the effects of incubation time may have been masked by multiple additional methodological factors significantly influencing the soil BDOC experiments in particular. For example, the presence of $\mathrm{O}_{2}$ within incubations or regular bottle shaking appeared to play a crucial role in soil BDOC losses (Table 2). As soil extractions typically have higher initial DOC concentrations (despite some degree of dilution applied in the experiment), they may be more susceptible to oxygen drawdown, increasing the importance of regular bottle shaking. Also, the method of assessing carbon loss appeared to play a critical role in the amount of BDOC measured during soil incubations, but not so clearly in aquatic experiments. This finding contradicts with the finding of McDowell et al. (2006) that found largely comparable results between available methods. We compared different methods conducted on different samples, which may explain our contrasting findings.
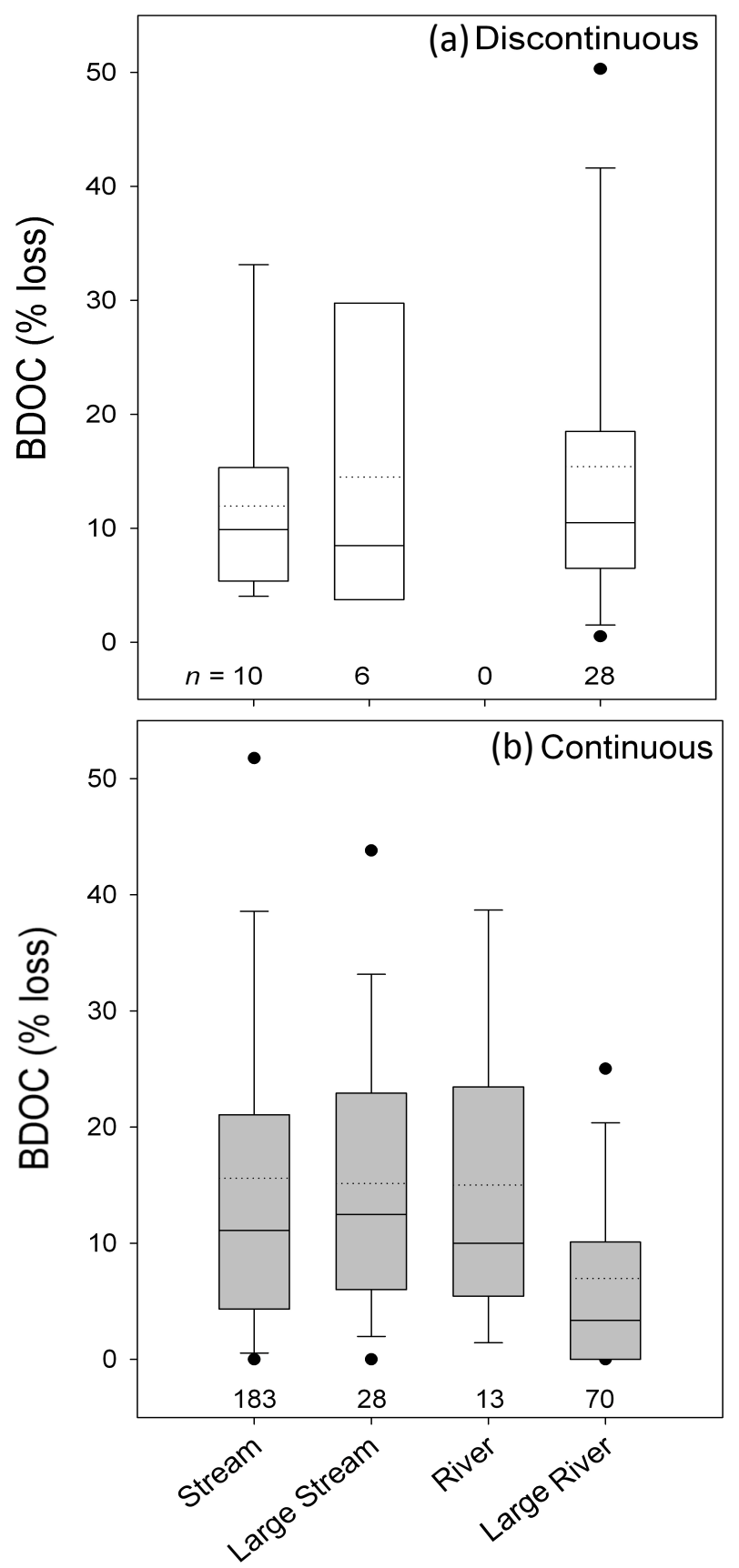

Figure 4. Aquatic BDOC data for $15-25^{\circ} \mathrm{C}$ after $28-34$ days incubation for streams $\left(<250 \mathrm{~km}^{2}\right)$, large streams $\left(>250 \mathrm{~km}^{2}\right.$, $\left.<25000 \mathrm{~km}^{2}\right)$, rivers $\left(>25000 \mathrm{~km}^{2},<500000 \mathrm{~km}^{2}\right)$, and large rivers $\left(>500000 \mathrm{~km}^{2}\right.$ ) clustered for (a) discontinuous and (b) continuous permafrost zones. Symbology as in Fig. 3. A plot for "no permafrost regions" is not shown as here only BDOC data for rivers were available (median $\mathrm{BDOC}=0.44 \%$, mean $\mathrm{BDOC}=0.69 \%$; $n=25$ ). The number of data points used are listed below the box plots. 


\subsection{Environmental factors influencing BDOC}

\subsubsection{Permafrost extent and longitude}

Aquatic and soil BDOC losses were significantly lower in regions without permafrost than in discontinuous or continuous permafrost regions (Fig. 3). This could be explained by shallower hydrologic flow paths in permafrost-affected regions, which would constrain water flow, and DOC origin, to relatively shallow soils. Or, alternatively, the unique dissolved organic matter (DOM) composition of yedoma permafrost (Abbott et al., 2014; Spencer et al., 2015), containing high levels of aliphatics and carbohydrates, could allow for more rapid degradation after thaw. Yedoma permafrost occupies a part of the continuous permafrost domain and its unique composition will therefore contribute to the composition of the DOC release from continuous permafrost. Furthermore, permafrost DOM is relatively well-preserved due to limited processing of organic carbon in soils under long-term frozen conditions (Khvorostyanov et al., 2008; Schuur et al., 2008), though permafrost-derived DOC still shows signs of processing (Wickland et al., 2012; Abbott et al., 2014). Continuous permafrost regions thus seem to receive relatively wellpreserved, unique DOC into soil leachates and aquatic systems leading to higher losses, whereas discontinuous permafrost regions and regions without permafrost receive DOC that has already been subject to some degree of degradation. The presence of permafrost also impacts hydrological flowpaths and transport times, which may result in a more efficient delivery of relatively less-processed terrestrial DOC to aquatic systems (Striegl et al., 2005; Walvoord et al., 2012). Alternatively, preferential sorption of specific compounds, freeze-thaw effects, or sub-zero metabolism in permafrost could increase DOC biodegradability (Abbott et al., 2014 and references therein). The difference in BDOC with permafrost extent is stronger in soils than in aquatic systems (Table 3, Fig. 3), likely attributable to a fresher, less altered permafrost DOC signature in soils compared to aquatic DOC that has already undergone some processing. Newly leached DOC from yedoma permafrost soils, representing part of our continuous permafrost soil data (Fig. 1), will be subject to more rapid degradation (Spencer et al., 2015).

Aquatic BDOC was negatively correlated with longitude. Judging from the prevailing geographical regions in the data set (Fig. 1) this suggests that aquatic BDOC in Alaska and Canada was on average higher than in Eastern Siberia. This could be related to a combination of the spatial spread in our data set with the distribution of yedoma. Yedoma is Pleistocene-aged permafrost (Zimov et al., 2006) predominantly present in northeast Siberia, but also in Alaska and NW Canada (Kanevskiy et al., 2011), that releases extremely biolabile DOC upon thaw (BDOC between $40-65 \%$ after 30-40 days of incubation, Vonk et al., 2013b; Abbott et al., 2014). In our meta-analysis, most of the aquatic BDOC in-
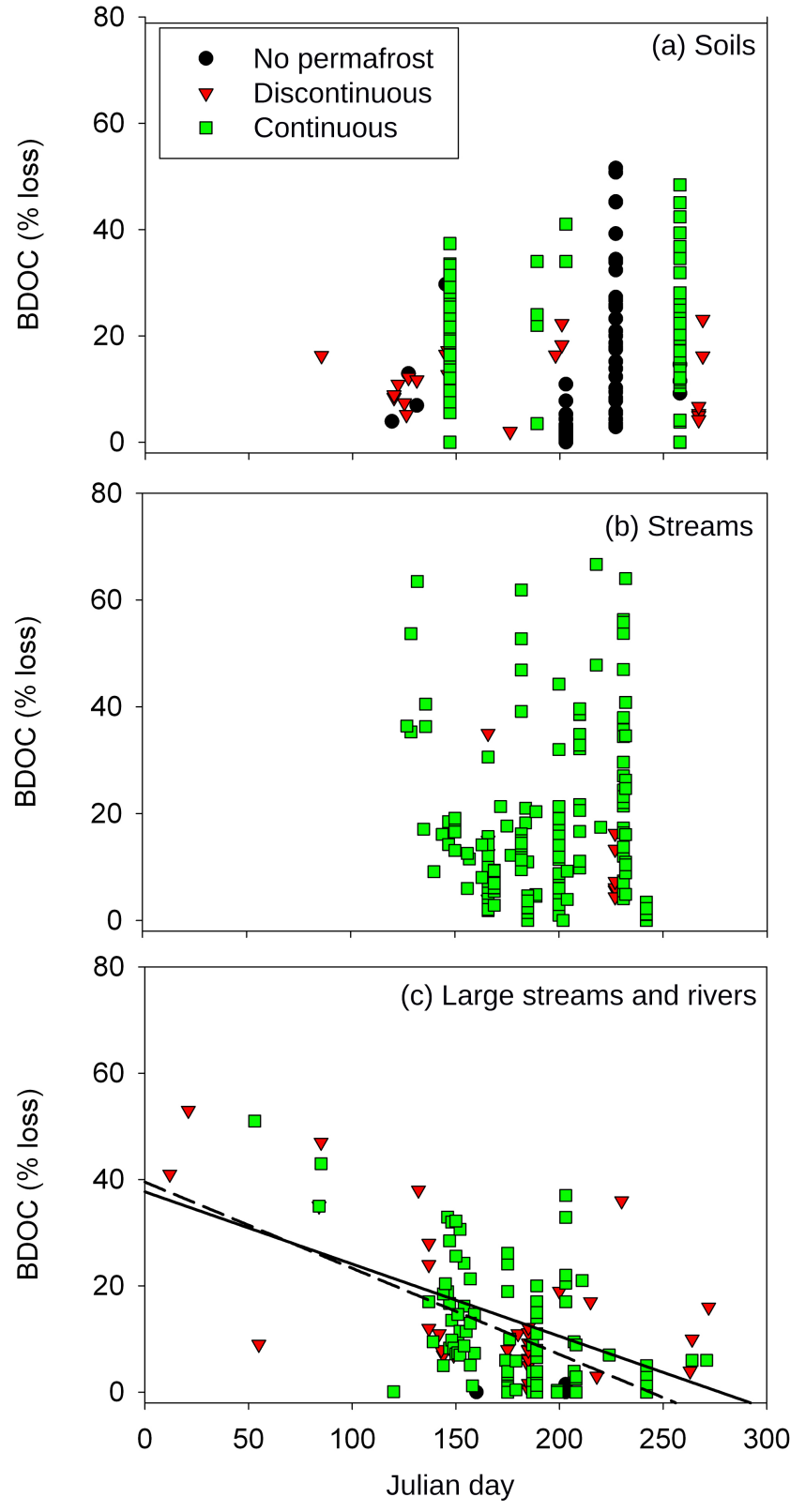

Figure 5. Seasonal BDOC losses (shown against Julian day) at $15-25^{\circ} \mathrm{C}$ after $28-34$ days incubation for (a) soil leachates, (b) streams and (c) clustered large streams, rivers and large rivers for regions without permafrost, discontinuous permafrost and continuous permafrost. Trend lines denote significant relationships where present. Solid line represents linear fit in discontinuous permafrost $\left(r^{2}=0.33, p=0.0003\right)$ and dashed line continuous permafrost $\left(r^{2}=0.29, p<0.0001\right)$.

cubations with yedoma-derived DOC are located in Alaska, which could explain the longitudinal pattern. 


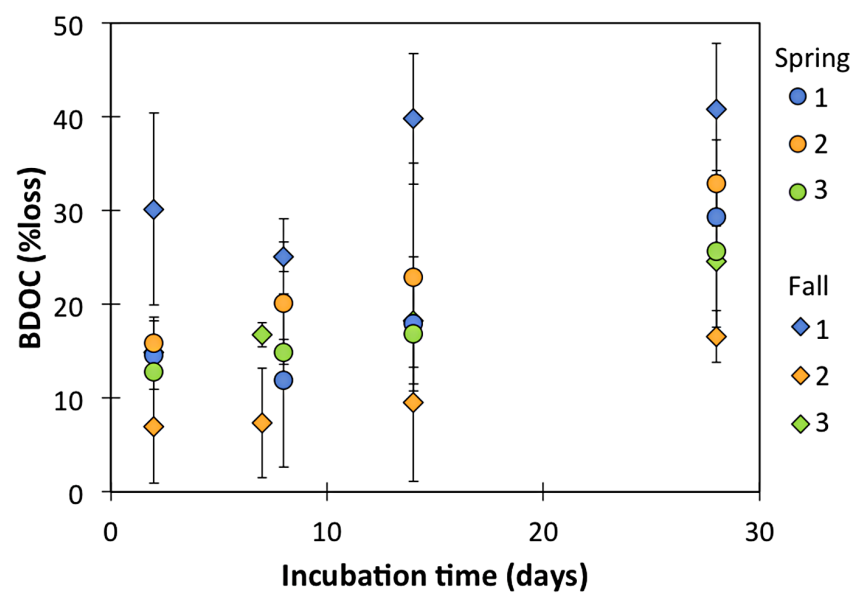

Figure 6. BDOC losses (at $20^{\circ} \mathrm{C}$ ) after 28-day incubation for soil leachates from three cores collected near Toolik, Alaska, as part of our circum-arctic incubation experiment (see Sect. 2.1). Soil leachates were collected and incubated both in spring (circles) and fall (diamonds). The three cores are indicated in blue (core 1), orange (core 2), and green (core 3 ). In core 1 we observed active plant growth during the spring and fall incubations.

\subsubsection{Patterns within the fluvial network}

In continuous permafrost regions, aquatic BDOC changes within the fluvial network (Fig. 4). Here, large rivers (defined as watersheds larger than $500000 \mathrm{~km}^{2}$ ) showed significantly lower BDOC than streams, large streams, and rivers. We should note here that streams $\left(<250 \mathrm{~km}^{2}, n=149\right)$ and large rivers $\left(>500000 \mathrm{~km}^{2}, n=60\right)$ are over-represented in the continuous permafrost data set, when compared to large streams $\left(250-25000 \mathrm{~km}^{2}, n=46\right)$ and rivers $(25000$ $\left.500000 \mathrm{~km}^{2}, n=18\right)$. Nevertheless, this suggests that continuous permafrost regions may release DOC that degrades more rapidly with the movement from headwaters to larger rivers in the fluvial network than DOC that is released from discontinuous permafrost regions or regions without permafrost. Pleistocene yedoma could be such a source, as its strong degradation potential (Vonk et al., 2013a, b; Abbott et al., 2014) leads to preferential utilization in headwater streams (Mann et al., 2015; Spencer et al., 2015).

\subsubsection{Seasonality}

BDOC decreased with Julian day for large streams, rivers and large rivers (Fig. 5c) in both continuous and discontinuous permafrost regions, whereas streams (Fig. 5b) and soil leachates (Fig. 5a) showed no seasonal pattern. This pattern may be associated with shifts in carbon source (winter and spring DOC in several Arctic rivers is more biolabile than in summer; Wickland et al., 2012; Mann et al., 2012; Holmes et al., 2008) but it is likely more related to a changing hydrologic residence time. In boreal and Arctic systems soil thaw-depth increases throughout the summer, resulting in longer water residence times in soils and headwater streams (Harms and Jones, 2012; Jones and Rinehart, 2010; Koch et al., 2013). This allows more time for biodegradable carbon compounds to be mineralized before reaching the river late in the season, effectively reducing measured BDOC in higherorder streams and rivers later in the season. Increasing water temperature through the season could magnify this effect with little mineralization early in the year when soils and streams are cold but accelerating biolabile carbon removal in summer. Hydrologic connectivity between soils and surface waters is generally weaker later in summer (Striegl et al., 2005; Spencer et al., 2008; Koch et al., 2013), which could explain the absence of seasonal trends for soils and streams (Fig. 5a, b). Furthermore, soil core leachates from a near-surface core that developed fresh plant growth during the growing season showed higher BDOC than cores without fresh plant growth (Fig. 6). These local plant growth-induced spikes in BDOC, likely induced by root exudates (Marschner and Kalbitz, 2003) could also mask seasonal trends in soil leachate BDOC and instead highlight spatial variability.

\subsubsection{Other factors affecting BDOC}

There are multiple factors that affect in situ BDOC that neither we nor the investigated literature studies have considered. One of these factors is the effect of light. Photochemical processes can lead to rapid DOC losses (up to $30 \%$ in 14 days; Mann et al., 2012) and may alter the DOC composition so that it is more susceptible to microbial degradation (Cory et al., 2013; Laurion and Mladenov, 2013). The presence of clay minerals can affect photochemical decomposition of DOC (Tietjen et al., 2005). Furthermore, POC also serves as an important catalyst in DOC biolability (Battin et al., 2008). In this study we do not investigate any potential co-metabolizing effects of POC degradation, or for the biodegradability of POC itself, which could be substantial (Sánchez-García et al., 2011; Richardson et al., 2013).

Something we could not directly address in our synthesis was the effect of DOM composition, which can be related to the depth of the active layer and the associated retention of certain fractions of the DOC pool. For example, sugars and microbially derived organic matter appear more biolabile than plant-derived organic matter (Balcarczyk et al., 2009; Mann et al., 2012). Also, permafrost DOM appears to be enriched in hydrogen-rich, aliphatic compounds that are preferentially degraded in incubation experiments (Spencer et al., 2015). The preferential degradation of biolabile components of the bulk DOC results in an enrichment of more recalcitrant components in soil pore waters (Wickland et al., 2007) and in larger rivers downstream (Spencer et al., 2015).

Another factor that could affect BDOC is nitrogen release from thawing permafrost (Harden et al., 2012; Keuper et al., 2012; Harms et al., 2014). High nitrogen levels have been found to correlate with high BDOC (Holmes et al., 2008; Wickland et al., 2012), although we do not find a strong cor- 


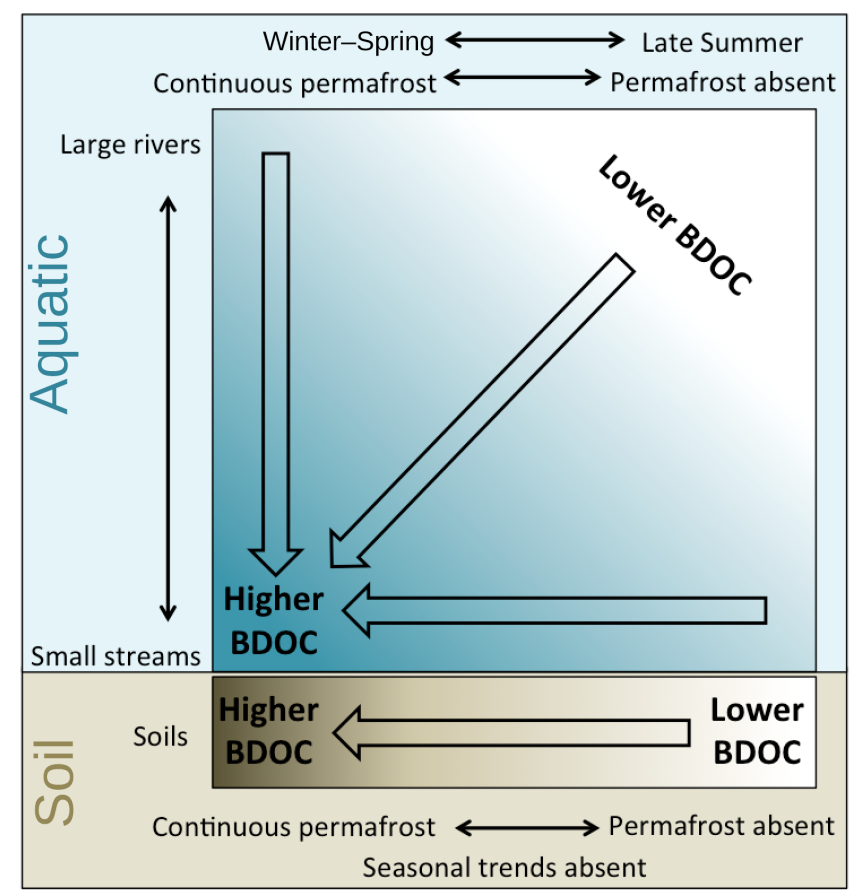

Figure 7. Conceptual graph of landscape-scale and seasonal trends in $\%$ BDOC where the upper blue box represents aquatic systems, and the lower brown box represents soils. Aquatic BDOC increases with decreasing catchment area, and aquatic and soil BDOC increase with increasing permafrost extent in the landscape. Aquatic BDOC in watersheds varies temporally, with more BDOC found in winter and spring than late summer.

relation in our meta-analysis and other studies show little response of BDOC to inorganic nutrient additions (Abbott et al., 2014; Mann et al., 2015).

\subsection{Circum-arctic patterns in BDOC}

\subsubsection{Geographical and seasonal patterns in BDOC}

We identified distinct large-scale patterns in the biodegradability of DOC, which we illustrate in a conceptual diagram (Fig. 7). The percentage BDOC in both soil and aquatic systems increased from regions without permafrost to regions with continuous permafrost. We attribute this increase to better preservation of DOC in permafrost regions where frozen storage has limited processing of the soil organic matter, and to stronger hydrologic connectivity between terrestrial and aquatic systems. Furthermore, within aquatic networks, BDOC was lower in large river systems compared with streams, and this pattern was most pronounced in continuous permafrost regions. This suggests that continuous permafrost regions release DOC sources such as Pleistocene yedoma that degrade rapidly in the fluvial network (Vonk et al., 2013b; Abbott et al., 2014; Mann et al., 2015; Spencer et al., 2015).
Aquatic BDOC in large streams and rivers decreased as the Arctic summer progressed. This pattern was absent for soils and streams. This could be related to a variety of factors such as seasonal shifts in carbon sources, changing DOC residence time related to increasing thaw-depth, increasing water temperatures later in the summer, as well as decreasing hydrologic connectivity between soils and surface waters when the season progresses. Alternatively, the integrating character of rivers and larger streams could mask localscale heterogeneity that is more apparent in small streams and soil leachates.

\subsubsection{Circum-arctic fluxes of BDOC}

Evaluating aquatic DOC export fluxes through sampling at river mouth locations near the Arctic Ocean underestimates the importance of the fluvial network for processing DOM. Literature estimates of watershed-scale aquatic $\mathrm{C}$ gas fluxes vary widely between 0.5 and $10 \mathrm{gC} \mathrm{m}^{-2} \mathrm{yr}^{-1}$ (all normalized to catchment area; Striegl et al., 2012; Lundin et al., 2013; Denfeld et al., 2013; Crawford et al., 2013). When extrapolated to the Arctic Ocean watershed $\left(20.5 \times 10^{6} \mathrm{~km}^{2}\right.$; Holmes et al., 2013) this could result in a total gaseous C emission between 10 and $200 \mathrm{Tg} \mathrm{Cyr}^{-1}$. These estimates seem reasonable compared to an annual Arctic Ocean watershed DOC flux of $34 \mathrm{Tg}$ (Holmes et al., 2012), where $34 \mathrm{Tg}$ is based on river mouth monitoring and ignores processing within the watershed prior to arriving at the river mouth. Also, a significant fraction of the emitted flux originates from weathering and soil respiration sources (Striegl et al., 2005; Humborg et al., 2009).

Wickland et al. (2012) estimated that the combined BDOC exported by the six largest Arctic rivers to the Arctic Ocean is

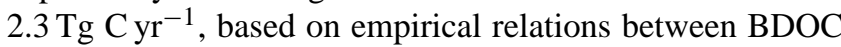
and DOC: DIN (dissolved inorganic nitrogen) ratios. Importantly, these watershed-scale estimates exclude processing and retention of DOC in soils, prior to delivery to aquatic networks. As we have seen in this study, soil BDOC is on average higher than aquatic BDOC. By using the \% permafrost extent in the Arctic Ocean watershed from Holmes et al. (2013), $45 \%$ continuous, $31 \%$ discontinuous (including sporadic and isolated) and $26 \%$ without permafrost, and average soil BDOC values for each permafrost zone $(20,15$ and 8 BDOC for continuous, discontinuous and no permafrost regions, respectively; mean values from Fig. 3b) we can calculate the permafrost-normalized average soil BDOC to be $16 \%$. Inclusion of DOC processing within soils is likely to significantly raise the $2.3 \mathrm{Tg} \mathrm{C} / \mathrm{yr}$ estimate for aquatic networks alone (Wickland et al., 2012). However, questions about the linkages between soil and stream BDOC with deepening active layer depths remain. Changes in hydrological flow paths associated with deepening active layers could reduce the inputs of DOC due to mineral sorption and additional processing during transport (MacLean et al., 1999; Striegl et al., 2005; O'Donnell et al., 2010) but the net ef- 
fects of permafrost thaw on BDOC inputs to streams are not yet well characterized.

\subsection{Method considerations and recommendations}

In order to compare BDOC losses across Arctic, and alternate systems, it is crucial to standardize the methods with which biodegradability is assessed. Our meta-analysis highlighted the significant variability in incubation design across the currently available literature making robust comparisons of BDOC across studies challenging. We suggest the following DOC incubation method, which is intentionally kept simple to be feasible at more remote field sites (a more detailed protocol is available in the supplementary information). Additionally, we suggest a few optional protocol steps that could be used to assess further environmental controls on BDOC.

\subsubsection{Standardized DOC incubation protocol}

- As soon as possible after collection, filter water samples through pre-combusted $\left(450^{\circ} \mathrm{C}>4 \mathrm{~h}\right) 0.7 \mu \mathrm{m}$ glass fiber filters and chill (ca. $4^{\circ} \mathrm{C}$ ) until ready to incubate.

- Rapid incubation setup is strongly recommended since many biolabile DOC compounds have turnover times of hours. We advocate against freezing samples due to DOC flocculation, compositional and structural changes in the DOC, and bacterial viability (Fellman et al., 2008).

- Decant filtrate into triplicate sets of $40 \mathrm{~mL}$ precombusted $\left(550^{\circ} \mathrm{C}>4 \mathrm{~h}\right)$ glass vials, and fill each vial with $30 \mathrm{~mL}$ filtrate. Use a triplicate glass vial set for each time point in your incubation. We recommend five time points at which one triplicate set will be consecutively removed from incubation: $T=0, T=2, T=7$, $T=14$ and $T=28$ days. Use clean caps with silicone or teflon septa (avoid rubber which can leach DOC). Potentially, a longer time step $(T=90$; e.g. Holmes et al., 2008) can be added to assess less labile DOC. In that case, we also recommend assessing DIC production (see additional protocol steps, below) as this method is more sensitive in detecting small changes. We want to point out, however, that the majority of the incubations will respond within 28 days, and longer incubations will introduce issues such as bottle effects.

- Our reasons for recommending 40mL glass vials are several; they are commonly available, they can be cleaned through pre-ashing, the required total volume per incubation is relatively small but sufficient for analysis, and our analyses suggest that variation in bottle size may affect BDOC results.

- Inoculation of samples is not needed as filtration through $0.7 \mu \mathrm{m}$ allows for a sufficient amount of bacteria to pass the filter.
- Incubate the vials in the dark (to avoid autotrophic respiration and photodegradation), with loose caps and regular shaking to avoid oxygen-depletion.

- We recommend performing sample incubation at room temperature $\left(20^{\circ} \mathrm{C}\right)$, as this is most common, relatively easy to maintain, and allows comparison between studies. This will provide the potential BDOC as $20^{\circ} \mathrm{C}$ is generally above ambient temperature. Document the temperature throughout the experiment precisely.

$\Rightarrow$ If possible, the incubations should be carried out at a stable temperature for example by using an oven or incubator.

- Re-filter the incubated samples through pre-combusted $\left(450{ }^{\circ} \mathrm{C}>4 \mathrm{~h}\right) 0.7 \mu \mathrm{m}$ filters (to avoid problems with flocculation and remove most microbial biomass) for each time step. Store the filtered samples in precombusted $\left(550^{\circ} \mathrm{C}>4 \mathrm{~h}\right) 40 \mathrm{~mL}$ glass vials, acidify to $\mathrm{pH} 2$ with $30 \mu \mathrm{L}$ concentrated $\mathrm{HCl}$. Cap tightly and store dark and chilled until analysis.

- For logistical reasons, we recommend assessment of BDOC through DOC loss (see Eq. 1).

- For details regarding DOC analysis, see the supplementary information. Note that samples with low initial DOC concentrations may approach the detection limit of OC analyzers.

\subsubsection{Additional protocol steps}

- Ambient incubation temperature: incubate at the ambient temperature of the water or soil from where the sample was collected to allow for application of results to ambient conditions. Run control incubations at $20^{\circ} \mathrm{C}$.

- Nutrient amendment: because the effect of nutrients on DOC processing is unclear, we recommend running experiments both with and without added nutrients. Amount of added nutrients should be adapted in relation to initial nutrient concentration according to the Redfield ratio, but in general an amendment of $\mathrm{NO}_{3}^{-}$ (to a concentration of $80 \mu \mathrm{m}), \mathrm{NH}_{4}^{+}(80 \mu \mathrm{m})$ and $\mathrm{PO}_{4}^{3-}$ (10 $\mu \mathrm{m}$; Holmes et al., 2008) is appropriate for aquatic and soil leachates. Run control incubations without nutrient amendment.

- DIC production: if field and laboratory settings allow we recommend also assessing $\mathrm{C}$ loss through DIC production, to provide BDOC estimates through two independent methods. We suggest to measure the $\mathrm{CO}_{2}$ concentration in the headspace of the incubation flask and calculate the change in DIC (headspace $\mathrm{CO}_{2}$ plus dissolved $\mathrm{CO}_{2}$, carbonate, and bicarbonate in the aqueous phase). This method is detailed in Kalbitz et al. (2003). 
Keep all other parameters (such as filter pore size, incubation temperature, and approximate sample volume) similar to the control incubation that measures DOC loss.

- Light incubation: dark incubations eliminate effects of autotrophic respiration and photodegradation; however to simulate realistic DOC drawdown, light is a critical factor (Mann et al., 2012; Cory et al., 2013).

- DOC "quality" (composition) measurements: If possible, we recommend assessing DOM compositional information for, at least, initial water samples or soil leachates and, if possible, also on incubated waters and soil leachates (i.e., post-incubation). These measures may include optical properties (specific ultraviolet absorbance, fluorescence excitation-emission matrices), and compound-specific analyses (carbohydrates, amino acids, lignin phenols, Fourier transform ion cyclotron resonance mass spectrometry, etc.). Note that short sample storage times are desirable for most analyses.

\section{Conclusions}

Half of the global belowground soil OC pool is stored in circum-arctic permafrost but little is known about the processes controlling transport and degradation of DOC, a key regulator of the rate of permafrost carbon release from the Arctic watershed to the atmosphere. We synthesized results from 14 BDOC studies from the permafrost region and complemented this with novel BDOC data determined using a standardized method from across the Arctic. We observed a large variability in soil and aquatic BDOC, even under uniform conditions. Despite the significant heterogeneity, we found that both soil and aquatic DOC is more biodegradable in regions with continuous permafrost compared to regions without permafrost. Within continuous permafrost regions, the degradability of DOC decreased from headwater streams to larger river systems, suggesting that permafrost DOC is preferentially utilized within the network. Furthermore, we discovered that aquatic BDOC in large streams and rivers decreased as the Arctic summer progressed, whereas this pattern was absent for soils and small streams.

Based on our synthesis of BDOC studies and additional measurements, we predict that slow future transformation of continuous permafrost into discontinuous permafrost regions could release an initial, relatively short-term, pulse of biodegradable DOC but will on longer timescales possibly lead to the release of DOC that is more recalcitrant. The total gaseous watershed C flux may, however, increase as more DOC could be processed within soils prior to release into aquatic networks due to deeper thaw depths and increasing residence time (Striegl et al., 2005). Furthermore, a lengthening of the arctic summer thaw period could result in lower
DOC biodegradability in large streams and rivers, but higher biodegradability in small streams and soils.

The Arctic is changing, and so is the coupling between its carbon and hydrologic cycles. There still are large uncertainties related to processing and transport of DOC, and few data are available from northern Canada and Russia, from discontinuous permafrost regions, and across all seasons. We strongly recommend that future studies of DOC degradability assess BDOC by means of our standardized DOC incubation protocol, to facilitate optimal use and integration of future data sets with existing knowledge.

\section{The Supplement related to this article is available online at doi:10.5194/bg-12-6915-2015-supplement.}

Acknowledgements. We would like to thank Greg Fiske for help with spatial analyses and creating Fig. 1. For financial support, we would like to thank the Dutch NWO (Veni grant \#863.12.004), the Permafrost Carbon Network, and the US-NSF (Arctic Great Rivers Observatory, The Polaris Project \#1044610, and Detecting the signature of permafrost thaw in Arctic rivers \#1203885; \#1500169), NSERC Discovery and Northern Research Supplement funds, the Graduate School at the University of New Hampshire, and USGS Climate and Land Use and Water Mission Areas. For field and laboratory support we would like to thank the Aurora Research Station in Inuvik, NWT/Canada, North-East Science Station, Cherskii/Russia (Nikita Zimov, Anya Davydova), the Woods Hole Research Center (Ekaterina Bulygina, Sue Natali), and Travis Drake (USGS). We thank Britta Voss (USGS) and Travis Drake (USGS) for comments on an early draft. Any use of trade or product names is for descriptive purposes only and does not imply endorsement by the US Government.

Edited by: I. Laurion 


\section{References}

Abbott, B. W., Jones, J. B., Schuur, E. A. G., Chapin III, F. S., Bowden, W. B., Bret-Harte, M. S., Epstein, H. E., Flannigan, M. D., Harms, T. K., Hollingsworth, T. N., Mack, M. C., McGuire, A. D., Natali, S. M., Rocha, A. V., Tank, S. E., Turetsky, M. R., Vonk, J. E., Wickland, K. P., and the Permafrost Carbon Network: Biomass offsets little or none of permafrost carbon release from soils, streams, and wildfire. An expert assessment, Environ. Res. Lett., submitted, 2015.

Abbott, B. W., Larouche, J. R., Jones, J. B., Bowden, W. B., and Balser, A. W.: Elevated dissolved organic carbon biodegradability from thawing and collapsing permafrost, J. Geophys. Res., 119, 2049-2063, 2014.

Aufdenkampe, A. K., Mayorga, E., Raymond, P. A., Melack, J. M., Doney, S. C., Alin, S. R., Aalto, R. E., and Yoo, K.: Riverine coupling of biogeochemical cycles between land, oceans, and atmosphere, Front. Ecol. Environ., 9, 53-60, 2011.

Avis, C. A., Weaver, A. J., and Meissner, K. J.: Reduction in areal extent of high-latitude wetlands in response to permafrost thaw, Nat. Geosci., 4, 444-448, 2011.

Balcarczyk, K. L., Jones, J. B., Jaffé, R., and Maie, N.: Stream dissolved organic matter bioavailability and composition in watersheds underlain with discontinuous permafrost, Biogeochemistry, 94, 255-270, 2009.

Battin, T. J., Kaplan, L. A., Findlay, S., Hopkinson, C. S., Marti, E., Packman, A. I., Newbold, J. D., and Sabater, F.: Biophysical controls on organic carbon fluxes in fluvial networks, Nat. Geosci. 1, 95-100, 2008.

Bradlow, E. T.: Exploring repeated measures data sets for key features using principal components analysis, Intern. J. Res. Market., 19, 167-179, 2002.

Cory, R. M., Crump, B. C., Dobkowski, J. A., and Kling, G. W.: Surface exposure to sunlight stimulates $\mathrm{CO}_{2}$ release from permafrost soil carbon in the Arctic, P. Natl. Acad. Sci. USA, 110, 3429-3434, 2013.

Crawford, J. T., Striegl, R. G., Wickland, K. P., Dornblaser, M. M., and Stanley, E. H.: Emissions of carbon dioxide and methane from a headwater stream network of interior Alaska, J. Geophys. Res.-Biogeosci., 118, 482-494, 2013.

del Giorgio, P. A. and Pace, M. L.: Relative independence of dissolved organic carbon transport and processing in a large temperate river: The Hudson River as both pipe and reactor, Limnol. Oceanogr. 53, 185-197, 2008.

Denfeld, B. A., Frey, K. E., Sobczak, W. V., Mann, P. J., and Holmes, R. M.: Summer $\mathrm{CO}_{2}$ evasion from streams and rivers in the Kolyma River basin, north-east Siberia, Polar Res., 32, 19704, doi:/10.3402/polar.v32i0.19704, 2013.

Fellman, J. B., D'Amore, D. V., and Hood, E.: An evaluation of freezing as a preservation technique for analyzing dissolved organic $\mathrm{C}, \mathrm{N}$ and $\mathrm{P}$ in surface water samples, Sci. Total Environ. 392, 305-312, 2008.

Frey, K. E. and McClelland, J. W.: Impacts of permafrost degradation on arctic river biogeochemistry, Hydrol. Process., 23, 169$182,2009$.

Harden, J. W., Koven, C. D., Ping, C.-L., Hugelius, G., McGuire, A. D., Camill, P., Jorgenson, T., Kuhry, P., Michaelson, G. J., O'Donnell, J. A., Schuur, E. A. G., Tarnocai, C., Johnson, K., and Grosse, G.: Field information links permafrost carbon to physi- cal vulnerabilities of thawing, Geophys. Res. Lett., 39, L15704, doi:10.1029/2012GL051958, 2012.

Harms, T. K. and Jones, J. B.: Thaw depth determines reaction and transport of inorganic nitrogen in valley bottom permafrost soils, Glob. Change Biol. 18, 2958-2968, 2012.

Harms, T. K., Abbott, B. W., and Jones, J. B.: Thermo-erosion gullies increase nitrogen available for hydrologic export, Biogeochemistry, 117, 299-311, 2014.

Holmes, R. M., McClelland, J. W., Raymond, P. A., Frazer, B. B., Peterson, B. J., and Stieglitz, M.: Lability of DOC transported by Alaskan rivers to the Arctic Ocean, Geophys. Res. Lett., 35, L03402, doi:10.1029/2007GL032837, 2008.

Holmes, R. M., McClelland, J. W., Peterson, B. J., Tank, S. E., Bulygina, E., Eglinton, T. I., Gordeev, V. V., Gurtovaya, T. Y., Raymond, P. A., Repeta, D. J., Staples, R., Striegl, R. G., Zhulidov, A. V., and Zimov, S. A.: Seasonal and annual fluxes of nutrients and organic matter from large rivers to the Arctic Ocean and surrounding seas, Estuar. Coast., 35, 369-382, 2012.

Holmes, R. M., Coe, M. T., Fiske, G. J., Gurtovaya, T., McClelland, J. W., Shiklomanov, A. I., Spencer, R. G. M., Tank, S. E., and Zhulidov, A. V.: Climate change impacts on the hydrology and biogeochemistry of Arctic rivers, in: Climatic Change and Global Warming of Inland Waters: Impacts and Mitigation for Ecosystems and Societies, edited by: Goldman, C. R., Kumagai, M., and Robarts, R. D., John Wiley \& Sons, Ltd, Chichester, United Kingdom, 3-26, 2013.

Hugelius, G., Strauss, J., Zubrzycki, S., Harden, J. W., Schuur, E. A. G., Ping, C.-L., Schirrmeister, L., Grosse, G., Michaelson, G. J., Koven, C. D., O’Donnell, J. A., Elberling, B., Mishra, U., Camill, P., Yu, Z., Palmtag, J., and Kuhry, P.: Estimated stocks of circumpolar permafrost carbon with quantified uncertainty ranges and identified data gaps, Biogeosciences, 11, 6573-6593, doi:10.5194/bg-11-6573-2014, 2014.

Humborg, C., Mörth, C.-M., Sundbom, M., Borg, H., Blenckner, T., Giesler, R., and Ittekkot, V.: $\mathrm{CO}_{2}$ supersaturation along the aquatic conduit in Swedish watersheds as constrained by terrestrial respiration, aquatic respiration and weathering, Glob. Change Biol., 16, 1966-1978, 2009.

IPCC: Climate Change 2013: The physical science basis, Contribution of Working group I to the Fifth Assessment Report of the Intergovernmental Panel on CLimate Change, edited by: Stocker, T. F., Qin, D., Plattner, G.-K., Tignor, M. M. B., Allen, S. K., Boschung, J., Nauels, A., Xia, Y., Bex, V., and Midgley, P. M., Cambridge University Press, Cambridge, UK and New York, USA, 1535 pp., 2013.

Jones, J. B. and Rinehart, A. J.: The long-term response of stream flow to climatic warming in headwater streams of interior Alaska, Can. J. For. Res. 40, 1201-1218, 2010.

Kalbitz, K., Schmerwitz, J., Schwesig, D., and Matzner, E.: Biodegradation of soil-derived dissolved organic matter as related to its properties, Geoderma, 113, 273-291, 2003.

Kanevskiy, M., Shur, Y., Fortier, D., Jorgenson, M. T., and Stephani, E.: Cryostratigraphy of late Pleistocene syngenetic permafrost (yedoma) in northern Alaska, Itkillik River exposure, Quat. Re., 75, 584-596, 2011.

Kawahigashi, M., Kaiser, K., Kalbitz, K., Rodionov, A., and Guggenberger, G.: Dissolved organic matter in small streams along a gradient from discontinuous to continuous permafrost, Glob. Change Biol., 10, 1576-1586, 2004. 
Keuper, F., van Bodegom, P. M., Dorrepaal, E., Weedon, J. T., van Hal, J., van Logtestijn, P., and Aerts, R.: A frozen feast: thawing permafrost increases plant-available nitrogen in subarctic peatlands, Glob. Change Biol., 18, 1998-2007, 2012.

Khvorostyanov, D. V., Ciais, P., Krinner, G., and Zimov, S. A.: Vulnerability of East Siberia's frozen carbon stores to future warming, Geophys. Res. Lett., 35, L10703, doi:10.1029/2008GL033639, 2008.

Kicklighter, D. W., Hayes, D. J., McClelland, J. W., Peterson, B. J., McGuire, A. D., and Melillo, J. M.: Insights and issues with simulating terrestrial DOC loading of Arctic river networks, Ecol. Appl., 23, 1817-1836, 2013.

Kiikkilä, O., Kitunen, V., and Smolander, A.: Properties of dissolved organic matter derived from silver birch and Norway spruce stands: degradability combined with chemical characteristics, Soil Biol. Biochem., 43, 421-430, 2011.

Kling, G. W., Kipphut, G. W., and Miller, M. C.: The flux of $\mathrm{CO}_{2}$ and $\mathrm{CH}_{4}$ from lakes and rivers in Arctic Alaska, Hydrobiologia, 240, 23-36, 1992.

Koch, J. C., Runkel, R. L., Striegl, R., and McKnight, D. M.: Hydrological controls on the transport and cycling of carbon and nitrogen in a boreal catchment underlain by discontinuous permafrost, J. Geophys. Res., 118, 698-712, 2013.

Lammers, R. B., Shiklomanov, A. I., Vorosmarty, C. J., Fekete, B. M., and Peterson, B. J.: Assessment of contemporary Arctic river runoff based on observational discharge records, J. Geophys. Res., 106, 3321-3334, 2001.

Larouche, J. R., Abbott, B. W., Bowden, W. B., and Jones, J. B.: The role of watershed characteristics, permafrost thaw, and wildfire on dissolved organic carbon biodegradability and water chemistry in Arctic headwater streams, Biogeosciences, 12, 42214233, doi:10.5194/bg-12-4221-2015, 2015.

Laudon, H., Buttle, J., Carey, S. K., McDonnell, J., McGuire, K., Seibert, J., Shanley, J., Soulsby, C., and Tetzlaff, D.: Crossregional prediction of long-term trajectory of stream water DOC response to climate change, Geophys. Res. Lett., 39, L18404, doi:10.1029/2012GL053033, 2012.

Laurion, I. and Mladenov, N.: Dissolved organic matter photolysis in Canadian arctic thaw ponds, Environ. Res. Lett., 8, 035026, doi:10.1088/1748-9326/8/3/035026, 2013.

Loveland, T. R., Reed, B. C., Brown, J. F., Ohlen, D. O., Zhu, Z., Yang, L., and Merchant, J. W.: Development of a global land cover characteristics database and IGBP DISCover from $1 \mathrm{~km}$ AVHRR data, Int. J. Remote Sens., 21, 1303-1330, 2000.

Lundin, E. J., Giesler, R., Persson, A., Thompson, M. S., and Karlsson, J.: Integrating carbon emissions from lakes and streams in a subarctic catchment, J. Geophys. Res., 118, 1-8, 2013.

Manisera, M., van der Kooij, A. J., and Dusseldorp, E.: Identifying the component structure of satisfaction scales by nonlinear principal components analysis, Qual. Technol. Quantitat. Manage., 7, 97-115, 2010.

Mann, P. J., Davydova, A., Zimov, N., Spencer, R. G. M., Davydov, S., Bulygina, E., Zimov, S., and Holmes, R. M.: Controls on the composition and lability of dissolved organic matter in Siberia's Kolyma River basin, J. Geophys. Res., 117, G01028, doi:10.1029/2011JG001798, 2012.

Mann, P. J., Eglinton, T. I., McIntyre, C. P., Zimov, N., Davydova, A., Vonk, J. E., Holmes, R. M., and Spencer, R. G. M.: Utilization of ancient permafrost carbon in headwaters of Arctic fluvial networks, Nat. Commun., 6, 7856, doi:10.1038/ncomms8856, 2015.

Marschner, B. and Kalbitz, K.: Controls of bioavailability and biodegradability of dissolved organic matter in soils, Geoderma, 113, 211-235, 2003.

McClelland, J. W., Stieglitz, M., Pan, F., Holmes, R. M., and Peterson, B. J.: Recent changes in nitrate and dissolved organic carbon export from the upper Kuparuk River, North Slope, Alaska, J. Geophys. Res., 112, G04S60, doi:10.1029/2006JG000371, 2007.

McDowell, W. H., Zsolnay, A., Aitkenhead-Peterson, J. A., Gregorich, E. G., Jones, D. L., Jödemann, D., Kalbitz, K., Marschner, B., and Schwesig, D.: A comparison of methods to determine the biodegradable dissolved organic carbon from different terrestrial sources, Soil Biol. Biochem., 38, 1933-1942, 2006.

McGuire, A. D., Anderson, L. G., Christensen, T. R., Dallimore, R., Guo, L., Hayes, D. J., Heimann, M., Lorenson, T. D., Macdonald, R. W., and Roulet, N.: Sensitivity of the carbon cycle in the Arctic to climate change, Ecol. Monogr., 79, 523-555, 2009.

Michaelson, G. J., Ping, C.-L., Kling, G. W., and Hobbie, J. E.: The character and bioactivity of dissolved organic matter at thaw and in the spring runoff waters of the arctic tundra north slope, Alaska, J. Geophys. Res., 103, 28939-28946, 1998.

O’Donnell, J. A., Aiken, G. R., Kane, E. S., and Jones, J. B.: Source water controls on the character and origin of dissolved organic matter in streams of the Yukon River basin, Alaska, J. Geophys. Res., 115, G03025, doi:10.1029/2009JG001153, 2010.

Olefeldt, D., Devito, K. J., and Turetsky, M. R.: Sources and fate of terrestrial dissolved organic carbon in lakes of a boreal plains region recently affected by wildfire, Biogeosciences, 10, 62476265, doi:10.5194/bg-10-6247-2013, 2013a.

Olefeldt, D., Turetsky, M. R., and Blodau, C.: Altered composition and microbial versus UV-mediated degradation of dissolved organic matter in boreal soils following wildfire, Ecosystems, 16, 1396-1412, doi:10.1007/s10021-013-9691-y, $2013 b$.

Petrone, K. C., Jones, J. B., Hinzman, L. D., and Boone, R. D.: Seasonal export of carbon, nitrogen, and major solutes from Alaskan catchments with discontinuous permafrost, J. Geophys. Res., 111, G02020, doi:10.1029/2005JG000055, 2006.

Quinn, G. P. and Keough, M. J. (Eds): Experimental design and data analysis for biologists, Cambridge University Press, Cambridge, United Kingdom, 2002.

Richardson, D. C., Newbold, J. D., Aufdenkampe, A. K., Taylor, P. G., and Kaplan, L. A.: Measuring heterotrophic respiration rates of suspended particulate organic carbon from stream ecosystems, Limnol. Oceanogr. Method., 11, 247-261, 2013.

Roehm, C. L., Giesler, R., and Karlsson, J.: Bioavailability of terrestrial organic carbon to lake bacteria: the case of a degrading subarctic permafrost mire complex, J. Geophys. Res., 114, G03006, doi:10.1029/2008JG000863, 2009.

Sánchez-García, L., Alling, V., Pugach, S., Vonk, J. E., van Dongen, B., Humborg, C., Dudarev, O, Semiletov, I., and Gustafsson, Ö.: Inventories and behavior of particulate organic carbon in the Laptev and East Siberian seas, Global Biogeochem. Cy., 25, GB2007, doi:10.1029/2010GB003862, 2011.

Schaefer, K., Lantuit, H., Romanovksy, V. E., Schuur, E. A. G., and Witt, R.: The impact of the permafrost carbon feedback on global climate, Environ. Res. Lett., 9, 085003, doi:10.1088/17489326/9/8/085003, 2014. 
Schuur, E. A. G., Bockheim, J., Canadell, J. G., Euskirchen, E., Field, C. B., Goryachkin, S. V., Hagemann, S., Kuhry, P., Lafleur, P. M., Lee, H., Mazhitova, G., Nelson, F. E., Rinke, A., Romanovksy, V. E., Shiklomanov, N., Tarnocai, C., Venevsky, S., Vogel, J. G., and Zimov, S. A.: Vulnerability of permafrost carbon to climate change: implications for the global carbon cycle, Bioscience, 58, 701-714, 2008.

Slater, A. G. and Lawrence, D. M.: Diagnosing Present and Future Permafrost from Climate Models, J. Climate, 26, 5608-5623, 2013.

Spencer, R. G. M., Aiken, G. R., Wickland, K. P., Striegl, R. G., and Hernes, P. J.: Seasonal and spatial variability in dissolved organic matter quantity and composition from the Yukon River basin, Alaska, Global Biogeochem. Cy., 22, GB4002, doi:10.1029/2008GB003231, 2008.

Spencer, R. G. M., Mann, P. J., Dittmar, T., Eglinton, T. I., McIntyre, C., Holmes, R. M., Zimov, N., and Stubbins, A.: Detecting the signature of permafrost thaw in Arctic rivers, Geophys. Res. Lett., 42, 2830-2835, 2015.

Striegl, R. G., Aiken, G. R., Dornblaser, M. M., Raymond, P. A., and Wickland, K. P.: A decrease in discharge-normalized DOC export by the Yukon River during summer to autumn, Geophys. Res. Lett., 32, L21413, doi:10.1029/2005GL024413, 2005.

Striegl, R. G., Dornblaser, M. M., McDonald, C. P., Rover, J. R., and Stets, E. G.: Carbon dioxide and methane emissions from the Yukon River system, Global Biogeochem. Cy., 26, GB0E05, doi:10.1029/2012GB004306, 2012.

Tank, S. E., Frey, K. E., Striegl, R. G., Raymond, P. A., Holmes, R. M., McClelland, J. W., and Peterson, B. J.: Landscapelevel controls on dissolved carbon flux from diverse catchments of the circumboreal, Glob. Biogeochem. Cy., 26, GB0E02, doi:10.1029/2012GB004299, 2012.

Tarnocai, C., Canadell, J. G., Schuur, E. A. G., Kuhry, P., Mazhitova, G., and Zimov, S.: Soil organic carbon pools in the northern circumpolar permafrost region, Global Biogeochem. Cy., 23, GB2023, doi:10.1029/2008GB003327, 2009.
Tietjen, T., Vähätalo, A. V., and Wetzel, R. G.: Effects of clay mineral turbidity on dissolved organic carbon and bacterial production, Aquat. Sci., 67, 51-60, 2005.

Vonk, J. E. and Gustafsson, Ö.: Permafrost-carbon complexities, Nat. Geosci., 6, 675-676, 2013.

Vonk, J. E., Mann, P. J., Dowdy, K. L., Davydova, A., Davydov, S. P., Zimov, N., Spencer, R. G. M., Bulygina, E. B., Eglinton, T. I., and Holmes, R. M.: Dissolved organic carbon loss from yedoma permafrost amplified by ice wedge thaw, Environ. Res. Lett., 8, 035023, doi:10.1088/1748-9326/8/3/035023, 2013a.

Vonk, J. E., Mann, P. J., Davydov, S., Davydova, A., Spencer, R. G. M., Schade, J., Sobczak, W. V., Zimov, N., Zimov, S., Bulygina, E., Eglinton, T. I., and Holmes, R. M.: High biolability of ancient permafrost carbon upon thaw, Geophys. Res. Lett., 40, 1-5, doi:10.1002/grl.50348, 2013b.

Walvoord, M.A., Voss, C. I., and Wellman, T. P.: Influence of permafrost distribution on groundwater flow in the context of climate-driven permafrost thaw: Example from Yukon Flats Basin, Alaska, United States, Water Resour, Res., 48, W07524, doi:10.1029/2011WR011595, 2012.

Wickland, K. P., Neff, J. C., and Aiken, G. R.: Dissolved organic carbon in Alaskan boreal forest: sources, chemical characteristics, and biodegradability, Ecosystems, 10, 1323-1340, 2007.

Wickland, K. P., Aiken, G. R., Butler, K., Dornblaser, M. M., Spencer, R. G. M., and Striegl, R. G.: Biodegradability of dissolved organic carbon in the Yukon River and its tributaries: seasonality and importance of inorganic nitrogen, Global Biogeochem. Cy., 26, GB0E03, doi:10.1029/2012GB004342, 2012.

Zimov, S.A., Davydov, S. P., Zimova, G. M., Davydova, A. I., Schuur, E. A. G., Dutta, K., and Chapin III, F. S.: Permafrost carbon: Stock and decomposability of a globally significant carbon pool, Geophys. Res. Lett., 33, L20502, doi:10.1029/2006GL027484, 2006. 